\title{
Hubungan Praktik Kesehatan pada Awal Kehidupan dengan Kejadian Stunting pada Balita
}

\section{Early Life Health Practice and Stunting Among Children Under-Five Years Old}

\author{
Sutrani Rachmawati, Putri Bungsu Machmud*, Ratna Djuwita Hatma \\ Departemen Epidemiologi, Fakultas Kesehatan Masyarakat Universitas Indonesia \\ ("putri.bungsu10@ui.ac.id)
}

\begin{abstract}
ABSTRAK
Banten memiliki prevalensi stunting tertinggi $(29,6 \%)$ di pulau Jawa dan terus mengalami peningkatan dalam tiga tahun terakhir. Praktik kesehatan seperti IMD, ASI eksklusif, MP-ASI, dan vitamin A sangatlah penting selama masa pertumbuhan di awal kehidupan. Tujuan penelitian ini untuk menganalisis hubungan praktik kesehatan pada awal kehidupan dengan kejadian stunting pada balita usia 6-23 bulan di Provinsi Banten. Penelitian ini menggunakan desain studi potong lintang dengan data sekunder PSG. Populasi penelitian ini adalah balita yang menjadi sampel PSG Provinsi Banten sebanyak 2438 balita. Sampel diambil secara total sampling dan terpilih 840 balita yang memenuhi kriteria inklusi. Analisis menggunakan uji chi-square dan regresi logistik ganda. Sebanyak 25,36\% mengalami stunting. Praktik kesehatan tidak berhubungan dengan kejadian stunting $(p=0,111)$ setelah dikontrol oleh variabel usia balita, jumlah anggota rumah tangga, pendidikan ibu, dan interaksi praktik kesehatan dengan pendidikan ibu. Namun, hasil uji interaksi menunjukan bahwa balita yang praktik kesehatannya tidak sesuai dan pendidikan ibunya tinggi berisiko 0,63 (95\%CI: 0,36-1,11) kali untuk menjadi stunting, dan balita yang praktik kesehatannya sesuai dan pendidikan ibunya rendah berisiko 1,82 (95\%CI: 0,90-3,67) kali untuk menjadi stunting. Praktik kesehatan tidak berhubungan dengan kejadian stunting, namun variabel interaksi praktik kesehatan dan pendidikan ibu berhubungan dengan kejadian stunting.
\end{abstract}

Kata kunci: Stunting, praktik kesehatan

\section{ABSTRACT}

Banten has the highest prevalence of stunting (29.6\%) on Java island and has increased in the last three years. Health practice such as early initiation of breastfeeding, exclusive breastfeeding, complementary feeding, and vitamin A was important during child's early life growth. This study analyzes the association between early life health practice and stunting among children aged 6-23 months in Banten 2017. This study used a cross-sectional design and used secondary data from PSG. The population in this study are the children aged 6-23 months who had become the sample of Banten Province PSG. Sampling used total sampling and selected 840 children who met the inclusion criteria. Analysis using chi-square test and multiple logistic regression. There were $25.36 \%$ of the child were stunting. There was no association between early life health practice and stunting $(p=0.111)$ after controlled by child's age, number of household, mother's education and the interaction between health practice ane mother's education. The interaction test showed that children who got inappropriate health practice and high mother's education was 0.63 times become stunting (95\% CI:0.36-1.11) and children who got appropriate health practice and low mother's education was 1.82 times become stunting (95\% CI:0.90-3.67). Health practice was not associated with stunting, but the interaction variables of health practice and mother's education was associated. Keywords: Stunting, health practices 


\section{PENDAHULUAN}

Stunting merupakan salah satu bentuk malnutrisi yang akan mempengaruhi kualitas kehidupan balita di masa mendatang. Stunting berdampak terhadap berkurangnya perkembangan kognitif dan fisik, mengurangi produktivitas, kondisi kesehatan yang buruk, dan berisiko untuk terkena penyakit degeneratif. ${ }^{1}$ Selain itu stunting pun memiliki konsekuensi untuk meningkatkan morbiditas, mortalitas, menurunnya kapasitas belajar, dan mengurangi kemampuan secara ekonomi. $^{2}$

Secara global, pada tahun 2017 prevalensi stunting pada balita mencapai $22,2 \%$ atau sekitar 151 juta balita. ${ }^{3}$ Persebaran stunting tertinggi terdapat di Oseania $(38,1 \%)$, Afrika Timur $(35,6 \%)$, dan Asia Selatan $(33,3 \%) .{ }^{4}$ Prevalensi stunting di Asia Tenggara mencapai $25,7 \%^{3}$, Indonesia sebagai negara berkembang masih memiliki tingkat prevalensi stunting yang tinggi yaitu sebesar $29,6 \%$ pada tahun 2017. ${ }^{4}$ Angka tersebut menunjukan bahwa stunting di Indonesia masih sebagai masalah kesehatan masyarakat karena tingkat prevalensi $>20 \%$. ${ }^{5}$ Salah satu provinsi dengan prevalensi stunting yang tinggi yaitu Provinsi Banten, dimana dalam tiga tahun terakhir prevalensi stunting mencapai 23,2\% (2015), 27\% (2016), dan 29,6\% (2017). ${ }^{4}$ Provinsi Banten merupakan provinsi yang memiliki prevalensi stunting tertinggi di Pulau Jawa dan terus mengalami peningkatan sejak tahun $2015 .{ }^{4}$

Stunting adalah kondisi balita yang panjang atau tinggi badan pada usianya memiliki nilai $z$-score $<-2$ SD jika dibandingkan dengan standar baku WHO-MGRS (Multicenter Growth Reference Study). ${ }^{6}$ Penyebab terjadinya stunting dikelompokkan menjadi tiga yaitu penyebab langsung, penyebab tidak langsung, dan penyebab dasar. ${ }^{7}$ Penyebab langsung terdiri dari faktor asupan gizi yang kurang dan penyakit yang menyerang individu. Penyebab tidak langsung terdiri dari ketahanan pangan rumah tangga, pola asuh dan pola makan yang kurang, serta lingkungan yang tidak sehat dan pelayanan kesehatan yang tidak memadai. Adapun faktor dasar meliputi faktor sosial, budaya, ekonomi, politik, akses rumah tangga terhadap sumber seperti pendidikan, pekerjaan, pendapatan dan teknologi.

Beberapa penelitian menunjukan bawah
Inisiasi Menyusui Dini (IMD), ASI eksklusif, pemberian MP-ASI dan vitamin A merupakan faktor yang berhubungan dengan kejadian stunting. . $^{8-11}$ Selain itu, usia dan jenis kelamin balita, pendidikan dan pekerjaan ibu, jumlah anggota rumah tangga, jumlah balita, dan tempat tinggal diteliti memilik hubungan dengan kejadian stunting. ${ }^{8,12,13}$ Di Indonesia sudah terdapat penelitian yang membahas hubungan faktor-fakor tersebut dengan kejadian stunting. Namun, pada penelitian ini akan diteliti lebih lanjut hubungan antara Inisiasi Menyusui Dini (IMD), ASI eksklusif, pemberian MPASI dan vitamin A dengan kejadian stunting dalam bentuk skoring (praktik kesehatan). Sehingga penelitian ini bertujuan melihat hubungan praktik kesehatan dengan kejadian stunting pada balita usia 6-23 bulan di Provinsi Banten.

\section{BAHAN DAN METODE}

Penelitian ini menggunakan desain studi potong lintang dengan data sekunder Pemantauan Status Gizi (PSG) Tahun 2017 . Penelitian dilakukan pada bulan November- Desember 2018 di Fakultas Kesehatan Masyarakat, Universitas Indonesia. Populasi pada penelitian ini adalah seluruh balita yang menjadi sampel PSG Provinsi Banten sebanyak 2483 balita. Sampel dalam penelitian ini adalah balita usia 6-23 bulan dengan kriteria inklusi tinggal bersama orang tua dan memiliki data yang lengkap. Keterangan tinggal bersama orang tua digunakan untuk melihat status pendidikan dan pekerjaan ibu. Total sampel yang terpilih sesuai kriteria inklusi adalah 840 balita.

Survei PSG menggunakan metode sampling klaster dua tahap. Tahap pertama, setiap kabupaten/kota dipilih 30 kelurahan/desa sebagai klaster. Tahap kedua yaitu memilih 10 rumah tangga yang memiliki balita di setiap klaster untuk dijadikan responden.

Variabel dependen dalam penelitian ini yaitu kejadian stunting yang dikategorikan menjadi stunting dan normal. Stunting dalam penelitian ini adalah balita yang memiliki status gizi berdasarkan indeks panjang/tinggi badan per usia dengan nilai $z$-score $<-2$ SD. ${ }^{14}$ Pengukuran panjang badan dilakukan secara berbaring terlentang menggunakan papan ukur panjang badan karena balita berusia $<2$ tahun. Namun, jika balita tidak ingin diukur secara terlentang, maka diukur dengan alat 
ukur berdiri (mikrotois).

Variabel independen utama yaitu praktik kesehatan yang merupaka hasil skoring dari variabel independen penyusun (praktik IMD, ASI eksklusif, pemberian MP-ASI, dan vitamin A). Masing-masing variabel independen penyusun diberikan coding 1, 2, dan 3. Coding dengan nilai terendah digunakan untuk kategori yang memiliki risiko tinggi dan semakin tinggi nilai coding maka digunakan untuk kategori yang memiliki risiko rendah. Hasil skoring memiliki distribusi tidak normal, sehingga nilai median dari data skoring dipergunakan sebagai cut off point kategori variabel praktik kesehatan yaitu hasil skoring tujuh. Kategori tersebut dibagi menjadi : sesuai jika hasil skoring $\geq 7$ dan tidak sesuai jika hasil skoring $<7$. Sedangkan praktik IMD dalam penelitian ini yaitu lama proses IMD yang dilakukan ibu saat setelah melahirkan yang terdiri menjadi tiga kategori, yaitu tidak melakukan IMD, melakukan proses IMD kurang dari 1 jam, dan melakukan proses IMD lebih atau sama dengan satu jam. ${ }^{15}$ Variabel ASI eksklusif diukur dengan melihat pada usia berapa balita diberi makanan atau minuman selain ASI. Dikatakan ASI eksklusif jika balita diberi makanan atau minuman selain ASI pada usia $\geq 6$ bulan. ${ }^{16}$

Variabel pemberian MP-ASI pada penelitian ini yaitu terkait waktu pertama kali balita mendapatkan MP-ASI yang dikategorikan menjadi 0-3 bulan, 4-5 bulan, dan $\geq 6$ bulan. ${ }^{17}$ Vitamin A dalam penelitian ini yaitu status balita terkait pernah atau tidaknya mendapatkan kapsul vitamin A yang didapatkan dari program pemerintah. Variabel kovariat terdiri dari usia balita, jenis kelamin balita, pendidikan ibu, pekerjaan ibu, jumlah anggota keluarga, jumlah balita, dan tempat tinggal. Pendidikan ibu dibagi menadi 2 kategori yaitu rendah jika hanya menyelesaikan pendidikan tingkat SMP atau dibawahnya, dan tinggi jika menyelesaikan pendidikan tingkat SMA ke atas. Pekerjaan dalam penelitian ini adalah kegiatan yang dilakukan oleh ibu untuk mendapatkan uang, sehingga kategori dibagi menjadi bekerja dan tidak bekerja. Jumlah anggota keluarga adalah jumlah orang yang tinggal bersama dalam satu rumah. Jumlah balita adalah ada atau tidaknya balita lain yang tinggal dalam satu rumah.

Analisis dilakukan secara univariat, bivariat dengan uji chi-square, dan multivariat dengan uji regresi logistik ganda. Aplikasi yang digunakan untuk analisis data dalam penelitian ini yaitu STATA 14.1. Penelitian ini telah lulus kaji etik dari Komisi Eetik Riset dan Pengabdian Kesehatan Masyarakat, Fakultas Kesehatan Masyarakat, Universitas Indonesia dengan nomor surat 789/UN2. F10/PPM.00.02/2018.

\section{Tabel 1. Distribusi Karakteristik Balita}

\begin{tabular}{|c|c|c|}
\hline Variabel & $\mathbf{n}$ & $\%$ \\
\hline \multicolumn{3}{|l|}{ Kejadian Stunting } \\
\hline Normal & 627 & 74,64 \\
\hline Stunting & 213 & 25,36 \\
\hline \multicolumn{3}{|l|}{ Praktik IMD } \\
\hline Tidak IMD & 341 & 40,6 \\
\hline $\mathrm{IMD}<1$ jam & 457 & 54,4 \\
\hline IMD $\geq$ jam & 42 & 5 \\
\hline \multicolumn{3}{|l|}{ ASI Eksklusif } \\
\hline Tidak ASI Eksklusif & 483 & 57,5 \\
\hline ASI Eksklusif & 357 & 42,5 \\
\hline \multicolumn{3}{|l|}{ Pemberian MP-ASI } \\
\hline $0-3$ bulan & 388 & 46,19 \\
\hline 4-5 bulan & 95 & 11,31 \\
\hline$\geq 6$ bulan & 357 & 42,5 \\
\hline \multicolumn{3}{|l|}{ Vitamin A } \\
\hline Tidak & 34 & 4,05 \\
\hline Ya & 806 & 95,95 \\
\hline \multicolumn{3}{|l|}{ Praktik Kesehatan } \\
\hline Sesuai $(\geq 7)$ & 433 & 51,55 \\
\hline Tidak Sesuai $(<7)$ & 407 & 48,45 \\
\hline \multicolumn{3}{|l|}{ Usia Balita } \\
\hline 6-11 bulan & 244 & 29,05 \\
\hline $12-23$ bulan & 596 & 70,95 \\
\hline \multicolumn{3}{|l|}{ Jenis Kelamin Balita } \\
\hline Perempuan & 403 & 47,98 \\
\hline Laki-laki & 437 & 52,02 \\
\hline \multicolumn{3}{|l|}{ Pendidikan Ibu } \\
\hline Tinggi & 350 & 41,67 \\
\hline Rendah & 490 & 58,33 \\
\hline \multicolumn{3}{|l|}{ Pekerjaan Ibu } \\
\hline Bekerja & 103 & 12,26 \\
\hline Tidak Bekerja & 737 & 87,74 \\
\hline \multicolumn{3}{|l|}{ Jumlah ART } \\
\hline$\leq 4$ orang & 670 & 79,76 \\
\hline$>4$ orang & 170 & 20,24 \\
\hline \multicolumn{3}{|l|}{ Jumlah Balita } \\
\hline Tidak Ada & 803 & 95,6 \\
\hline Ada & 37 & 4,4 \\
\hline \multicolumn{3}{|l|}{ Tempat Tinggal } \\
\hline Perkotaan & 376 & 44,76 \\
\hline Pedesaan & 464 & 55,24 \\
\hline
\end{tabular}

Sumber : Kementerian Kesehatan RI, 2017 
HASIL

Distribusi responden berdasarkan karakteristik dapat dilihat pada Tabel 1. Prevalensi stunting pada balita usia 6-23 bulan di Provinsi Banten sebesar 25,36\%. Balita dalam penelitian ini lebih banyak yang mendapatkan praktik IMD $<1$ jam $(54,4 \%)$, tidak ASI eksklusif (57,5\%), diberikan MP-ASI pada usia 0-3 bulan (46,19\%), mendapatkan vitamin A (95,95\%), dan praktik kesehatan yang sesuai, yaitu memiliki nilai skoring lebih atau sama dengan tujuh dari praktik IMD, MP-ASI, ASI eksklusif dan vitamin A (51,55\%). Mayoritas balita berusia $12-23$ bulan $(70,95 \%)$ dan berjenis kelamin laki-laki $(52,02 \%)$. Ibu balita lebih banyak yang memiliki pendidikan rendah $(58,33 \%)$ dan tidak bekerja $(87,74 \%)$. Sebagian besar balita memiliki jumlah anggota rumah tangga $\leq 4$ orang $(79,76 \%)$, tidak ada balita yang tinggal dalam satu rumah $(95,6 \%)$, dan tinggal di daerah pedesaan $(55,24 \%)$ (Tabel 1).

Berdasarkan hasil analisis bivariat, variabel yang signifikan berhubungan dengan kejadian stunting adalah usia balita $(\mathrm{p}=0,000)$ dan jumlah anggota rumah tangga $(p=0,008)$. Sedangkan praktik kesehatan, jenis kelamin balita, pendidikan ibu, pekerjaan ibu, jumlah balita, dan tempat tinggal tidak berhubungan dengan kejadian stunting ( $\mathrm{p}$ $>0,05$ ) (Tabel 2).

Hasil analisis multivariat menunjukan bahwa tidak ada hubungan yang signifikan antara praktik kesehatan dengan kejadian stunting setelah dikontrol oleh variabel usia balita dan jumlah anggota rumah tangga, serta interaksi dengan variabel pendidikan ibu $(p=0,111)$. Namun, adanya interaksi dengan variabel pendidikan ibu, maka perlu adanya perhitungan nilai OR untuk masingmasing interkasi (Tabel 3).

Setelah perhitungan OR interaksi menunjukkan bahwa balita yang praktik kesehatannya tidak sesuai dan pendidikan ibunya rendah memiliki risiko 1,15 (95\%CI: 0,32-4,06) kali untuk menjadi stunting dibandingkan balita yang praktik kesehatannya sesuai dan pendidikan ibunya tinggi. Balita yang praktik kesehatannya tidak sesuai dan pendi-

Tabel 2. Analisis Bivariat Variabel yang Berhubungan dengan Kejadian Stunting

\begin{tabular}{|c|c|c|c|c|}
\hline Variabel & $\begin{array}{c}\text { Normal } \\
\text { n (\%) }\end{array}$ & $\begin{array}{c}\text { Stunting } \\
\text { n (\%) }\end{array}$ & p value & POR (95\% CI) \\
\hline \multicolumn{5}{|l|}{ Praktik Kesehatan } \\
\hline Sesuai $(\geq 7)$ & $322(73,85)$ & $111(26,15)$ & 0,802 & $0,96(0,66-1,38)$ \\
\hline Tidak Sesuai $(<7)$ & $305(74,71)$ & $102(25,29)$ & & \\
\hline \multicolumn{5}{|l|}{ Usia Balita } \\
\hline 6-11 bulan & $233(95,38)$ & $11(4,62)$ & $0,000 *$ & $10,68(4,92-23,18)$ \\
\hline $12-23$ bulan & $394(65,92)$ & $202(34,08)$ & & \\
\hline \multicolumn{5}{|l|}{ Jenis Kelamin } \\
\hline Perempuan & $310(77,41)$ & $93(22,59)$ & 0,082 & $1,37(0,96-1,95)$ \\
\hline Laki-laki & $317(71,47)$ & $120(28,53)$ & & \\
\hline \multicolumn{5}{|l|}{ Pendidikan Ibu } \\
\hline Tinggi & $282(79,32)$ & $68(20,68)$ & 0,056 & $1,60(0,98-2,58)$ \\
\hline Rendah & $345(70,63)$ & $145(29,37)$ & & \\
\hline \multicolumn{5}{|l|}{ Pekerjaan Ibu } \\
\hline Bekerja & $78(68,69)$ & $25(31,31)$ & 0,417 & $0,72(0-32-1,62)$ \\
\hline Tidak Bekerja & $594(75,2)$ & $188(24,8)$ & & \\
\hline \multicolumn{5}{|l|}{ Jumlah Anggota } \\
\hline$\leq 4$ orang & $514(76,43)$ & $156(23,57)$ & $0,008^{*}$ & $1,71(1,16-2,54)$ \\
\hline$>4$ orang & $113(65,42)$ & $57(34,58)$ & & \\
\hline \multicolumn{5}{|l|}{ Jumlah Balita } \\
\hline Tidak Ada & $597(73,92)$ & $206(26,08)$ & 0,285 & $0,63(0,26-1,51)$ \\
\hline Ada & $30(81,83)$ & $7(18,17)$ & & \\
\hline \multicolumn{5}{|l|}{ Tempat Tinggal } \\
\hline Perkotaan & $290(76,58)$ & $86(23,42)$ & 0,261 & $1,21(0,86-1,71)$ \\
\hline Pedesaan & $337(72,97)$ & $127(27,03)$ & & \\
\hline
\end{tabular}

Sumber : Kementerian Kesehatan RI, 2017 
Tabel 3. Final Model Hasil Analisis Multivariat

\begin{tabular}{lccccc}
\hline \multicolumn{1}{c}{ Variabel } & B & S.E & $p$-value & OR & 95\% CI \\
\hline Praktik Kesehatan & $-0,46$ & 0,29 & 0,111 & 0,63 & $0,36-1,11$ \\
Usia Balita & 2,37 & 0,32 & 0,000 & 10,68 & $5,69-20,07$ \\
& & & & & \\
& 0,40 & 0,20 & 0,047 & 1,49 & $1.00-2,20$ \\
Jumlah Anggota Rumah Tangga & 0,26 & 0,24 & 0,269 & 1,30 & $0,81-2,08$ \\
Pendidikan Ibu & & & & & $0,90-3,67$ \\
Praktik Kesehatan by Pendidikan Ibu* & 0,60 & 0,36 & 0,092 & 1,82 & 0,902 \\
\end{tabular}

Sumber : Kementerian Kesehatan RI, 2017

Tabel 4. Hasil perhitungan OR interaksi

\begin{tabular}{lccc}
\hline \multicolumn{1}{c}{ Variabel } & Perhitungan & OR & 95 \% CI \\
\hline Praktik Kesehatan (1), Pendidikan Ibu (1) & Exp [(-0,46) (1) +(0,60)(1)] & 1,15 & $0,32-4,06$ \\
Praktik Kesehatan (1), Pendidikan Ibu (2) & Exp [(-0,46)(1)+(0,60)(2)] & 0,63 & $0,36-1,11$ \\
Praktik Kesehatan (2), Pendidikan Ibu (1) & Exp [(-0,46)(2)+(0,60)(1)] & 1,82 & $0,90-3,67$ \\
Praktik Kesehatan (2), Pendidikan Ibu (2) & Exp [(-0,46) (2)+(0,60)(2)] & 1 & Ref \\
\hline
\end{tabular}

Sumber : Kementerian Kesehatan RI, 2017

dikan ibunya tinggi memiliki risiko $0,63(95 \% \mathrm{CI}$ : 0,36-1,11) kali untuk menjadi stunting dibandingkan balita yang praktik kesehatannya sesuai dan pendidikan ibunya tinggi. Balita yang praktik kesehatannya sesuai dan pendidikan ibunya rendah memiliki risiko 1,82 (95\%CI:0,90-3,67) kali untuk menjadi stunting dibandingkan balita yang praktik kesehatannya sesuai dan pendidikan ibunya tinggi (Tabel 4).

\section{PEMBAHASAN}

Penelitian ini menggunakan data sekunder sehingga peneliti tidak memiliki kendali terhadap kualitas data. Penelitian ini tidak mengikutsertakan faktor-faktor lain yang juga berhubungan dengan kejadian stunting seperti status berat badan lahir rendah (BBLR), status ekonomi rumah tangga, panjang badan lahir, pengetahuan gizi ibu, dan riwayat penyakin infeksi. ${ }^{16-19}$

Prevalensi stunting pada balita usia 6-23 bulan di Provinsi Banten tahun 2017 adalah 25,36\%. Angka tersebut termasuk dalam kategori tinggi $(>20 \%)$ dan menjadi masalah kesehatan masyarakat. ${ }^{5}$ Hasil penelitian ini menunjukan bahwa tidak ada hubungan yang signifikan secara statistik antara praktik kesehatan dengan kejadian stunting. Hasil ini kemungkinan dipengaruhi oleh adanya proses skoring dan cut off point yang digunakan untuk pengkategorian tidak terlalu sensitif oleh karena pengukuran terkait empat variabel inde- penden utama masih memiliki beberapa potensial bias informasi. Pada studi ini pengukuran IMD hanya dinilai berdasarkan durasi tanpa menilai proses IMD, sehingga tidak dapat dipastikan balita mendapatkan kolostrum dari ibu. Selain itu kualitas pemberian ASI ekslusif tidak dapat dinilai pada studi ini. Pada variabel pemberian vitamin A, studi ini hanya mengukur berdasarkan pemberian vitamin A dengan frekuensi dua kali setahuan (program kementrian kesehatan) tanpa menilai asupan harian. Penelitian yang menghubungkan hasil skoring dari variabel praktik IMD, ASI eksklusif, pemberian MP-ASI, dan pemberian vitamin A terhadap kejadian stunting belum pernah dilakukan sebelumnya di Indonesia. Namun beberapa penelitian membuktikan bahwa masing-masing dari variabel praktik IMD, ASI eksklusif, pemberian MP-ASI, dan vitamin A berhubungan dengan kejadian stunting.

Penelitian di Boyolali menunjukan bahwa balita yang tidak mendapatkan praktik IMD memiliki risiko 2,6 (95\%CI:1,02 - 6,82) kali menjadi stunting dibandingkan balita yang mendapatkan praktik IMD. ${ }^{20}$ Hasil ini sejalan dengan penelitian yang dilakukan di Bengkulu, Jambi, dan Republik Kongo ${ }^{8,11,15}$ Hasil penelitian di Makasar menemukan bahwa balita yang tidak diberikan ASI secara eksklusif lebih berisiko 5,52 (95\%CI : 2,70-11,27) kali untuk mengalami stunting dibandingkan balita yang diberi ASI secara eksklusif. ${ }^{6}$ Hasil terse- 
but didukung juga oleh hasil penelitian lainnya di Kota Banda Aceh, Pekanbaru, dan Sumedang . 21-23 $^{2}$ Penelitian di Ethiopia Utara menemukan hasil bahwa balita yang diberikan MP-ASI untuk pertama kalinya pada usia sebelum 6 bulan memiliki risiko 2,4 kali $(95 \%$ CI : 1,26-4,66) untuk menjadi stunting. ${ }^{13}$ Hasil tersebut sesuai dengan hasil penelitian di Kecamatan Sedayu, Daerah Istimewa Yogyakarta. ${ }^{10}$ Penelitian di Bengkulu memperoleh hasil bahwa balita yang tidak pernah diberikan kapsul vitamin A memiliki risiko 2,4 (95\%CI: 1,57-3,67) kali untuk menjadi stunting dan hasil ini serupa dengan penelitian yang dilakukan di Semarang. ${ }^{11,24}$ Menurut WHO praktik IMD, ASI eksklusif, dan MP-ASI merupakan hal penting pada 2 tahun awal kehidupan balita yang akan berpengaruh terhadap pertumbuhan dan perkembangan selanjutnya..$^{25}$ Melalui IMD dan ASI eksklusif memungkinkan balita mendapatkan kolostrum yang mengandung antibodi sehingga sistem kekebalan tubuh bayi menjadi baik. Sedangkan vitamin A adalah mikronutrien yang memiliki peran pen-ting dalam sistem kekebalan tubuh, ${ }^{26}$ jika sistem kekebalan tubuh balita baik maka akan terhindar dari penyakit infeksi yang mampu berpengaruh terhadap pertumbuhan. ${ }^{7}$

Hasil uji interaksi menunjukan bahwa ada interaksi anatara praktik kesehatan dengan pendidikan ibu. Balita yang praktik kesehatannya tidak sesuai dan pendidikan ibunya rendah tidak berhubungan dengan kejadian stunting $(\mathrm{OR}=1,15$; 95\%CI: 0,32-4,06). Balita yang praktik kesehatannya tidak sesuai dan pendidikan ibunya tinggi memberikan pengaruh protektif terhadap kejadian stunting $(\mathrm{OR}=0,63 ; 95 \% \mathrm{CI}: 0,36-1,11)$ dibandingkan balita yang praktik kesehatannya sesuai dan pendidikan ibunya tinggi. Sedangkan pada balita yang praktik kesehatannya sesuai dan pendidikan ibunya rendah memiliki irisko 1,82 (95\%CI: 0,903,67 ) kali untuk menjadi stunting dibandingkan balita yang praktik kesehatannya sesuai dan pendidikan ibunya tinggi. Hasil interaksi tersebut menunjukan bahwa pendidikan ibu secara konsisten berpengaruh terhadap kejadian stunting. Sehingga besar hubungan praktik kesehatan dengan kejadian stunting bermakna secara statistik pada variabel interaksi praktik kesehatan dengan pendidikan ibu. Hasil ini sesuai dengan penelitian yang dilakukan di Ethiopia Utara, ibu dengan pen- didikan tinggi dapat mengurangi risiko stunting pada balita dibandingkan ibu dengan pendidikan rendah. ${ }^{13}$ Status pendidikan yang tinggi memungkinkan ibu untuk memperhatikan pengasuhan yang baik, seperti pemberian makan dengan gizi seimbang, menjaga kebersihan balita, dan perawatan kesehatan yang dapat meningkatkan status gizi balita. ${ }^{13}$

Kelebihan dalam penelitian ini yaitu melakukan skoring terhadap variabel praktik IMD, ASI eksklusif, pemberian MP-ASI, dan pemberian vitamin A yang belum pernah dilakukan sebelumnya. Namun, kelemahannya belum mampu menentukan cut off point yang lebih sensitif untuk membagi kategori praktik kesehatan yang sesuai dan tidak sesuai.

\section{KESIMPULAN DAN SARAN}

Praktik kesehatan tidak berhubungan dengan kejadian stunting pada balita usia 6-23 bulan di Provinsi Banten. Namun, ada hubungan yang bermakna secara statistik antara variabel interaksi praktik kesehatan dan pendidikan ibu dengan kejadian stunting. Sehingga program intervensi untuk pencegahan stunting perlu menyentuh perbaikan pendidikan ibu, seperti mengadakan kelas parenting bagi ibu hamil dan ibu yang memiliki balita. Bagi penelitian selanjutnya perlu menggunakan sumber data yang lebih detail terkait empat variabel utama yaitu IMD, ASI eksklusif, MP-ASI dan vitamin A sehingga pengukuran cut off point menjadi lebih sensitif untuk skoring variabel praktik kesehatan. Selain itu, peneliti selanjutnya dapat mempertimbangkan untuk mengikutsertakan faktor lain yang diduga berhubungan dengan kejadian stunting, seperti BBLR, sanitasi lingkungan dan Panjang Badan saat lahir.

\section{UCAPAN TERIMA KASIH}

Terimakasih pada Direktorat Gizi Masyarakat, Kementrian Kesehatan RI yang memberikan izin untuk menggunakan data Pemantauan Status Gizi Provinsi Banten Tahun 2017.

\section{DAFTAR PUSTAKA}

1. United Nations Children's Fund. Improving child nutrition. New York: United Nations Children's Fund; 2013.

2. Stewart CP, Iannotti L, Dewey KG, Mi- 
chaelsen KF, Onyango AW. Contextualising complementary feeding in a broader framework for stunting prevention. Maternal \& child nutrition. 2013;9:27-45

3. United Nations Children's Fund, World Health Organization, The World Bank Group. Levels and trends in child malnutrition. New York; 2018.

4. Kementrian Kesehatan, Direktorat Gizi Masyarakat. Pemantauan status gizi tahun 2017. Jakarta: Kementrian Kesehatan RI; 2017

5. World Health Organization [Internet]. Geneva: Cut-off points and summary statistics; [cited 2018 January 10]. Available from:https:// www.who.int/nutgrowthdb/about/introduction/en/index 5 .html.

6. World Health Organization [Internet]. Geneva: The WHO child growth standards; [cited 2018 January 10]. Available from: https:// www.who.int/childgrowth/en/.

7. United Nations Children's Fund. UNICEF's approach to scaling up nutrition for mothers and their children. New York; 2015.

8. Kismul H, Acharya P, Mapatano MA, Hatløy A. Determinants of childhood stunting in the Democratic Republic of Congo: further analysis of Demographic and Health Survey 201314. BMC public health. 2018;18(1):1-14

9. Lestari ED, Hasanah F, Nugroho NA. Correlation between non-exclusive breastfeeding and low birth weight to stunting in children. Paediatrica Indonesiana. 2018;58(1):123-7.

10. Khasanah DP, Hadi H, Paramashanti BA. Waktu pemberian makanan pendamping ASI (MP-ASI) berhubungan dengan kejadian stunting anak usia 6-23 bulan di Kecamatan Sedayu. Jurnal Gizi dan Dietetik Indonesia (Indonesian Journal of Nutrition and Dietetics). 2016;4(2):105-11.

11. Simanjuntak BY, Haya M, Suryani D, Ahmad CA. Early Inititation of Breastfeeding and Vitamin A Supplementation with Nutritional Status of Children Aged 6-59 Months. Kesmas: National Public Health Journal. 2018;12(1):107-13.

12. García Cruz L, Gonzalez Azpeitia G, Reyes Suarez D, Santana Rodríguez A, Loro Ferrer J, Serra-Majem L. Factors associated with stunting among children aged 0 to 59 months from the central region of Mozambique. Nutrients. 2017;9(5):491.

13. Abeway S, Gebremichael B, Murugan R, Assefa M, Adinew YM. Stunting and Its Determinants among Children Aged 6-59 Months in Northern Ethiopia: A Cross-Sectional Study. Journal of nutrition and metabolism. 2018;2018(1078480):1-8

14. Keputusan Mentri Kesehatan Republik Indonesia Nomor 10 Tentang Standar Antropometri Penilaian Status Gizi Anak.

15. Laksminingsih E. Can early initiation to breastfeeding prevent stunting in 6-59 months old children? Journal of Health Research. 2018;32(5):334-41.

16. Utami Hamdany Sakti A, Saifuddin Sirajuddin. Risk factors of stunting case on children aged 24-59 months in slums of makassar city IOSR Journal of Nursing and Health Science. 2018;7(1):17-22.

17. Paramashanti BA, Hadi H, Gunawan IMA. Pemberian ASI eksklusif tidak berhubungan dengan stunting pada anak usia 6-23 bulan di Indonesia. Jurnal Gizi dan Dietetik Indonesia Indonesian Journal of Nutrition and Dietetics. 2016;3(1):162-74.

18. Ni'mah K, Nadhiroh SR. Faktor yang berhubungan dengan kejadian stunting pada balita. Media Gizi Indonesia. 2016;10(1):13-9

19. Paramashanti BA, Paratmanitya Y, Marsiswati M. Individual dietary diversity is strongly associated with stunting in infants and young children. Jurnal Gizi Klinik Indonesia. 2017;14(1):19-26.

20. Permadi MR. Hubungan Inisiasi Menyusu Dini dan Air Susu Ibu Eksklusif Dengan Kejadian Stunting pada Anak Usia 6-24 bulan di Kabupaten Boyolali [Tesis]. Surakarta: Universitas Sebelas Maret; 2016.

21. Rahmad AHA, Miko A. Kajian Stunting pada Anak Balita berdasarkan Pola Asuh dan Pendapatan Keluarga Di Kota Banda Aceh. Kesmas Indonesia. 2016;8(02):63-79.

22. Fitri L. Hubungan BBLR Dan Asi Ekslusif Dengan Kejadian Stunting Di Puskesmas Lima Puluh Pekanbaru. Jurnal Endurance: Kajian Ilmiah Problema Kesehatan. 2018;3(1):131-7.

23. Subandra Y, Zuhairini Y, Djais J. Hubungan pemberian ASI Eksklusif dan Makanan Pen- 
damping ASI terhadap Balita Pendek Usia 2 sampai 5 tahun di Kecamatan Jatinangor. Jurnal Sistem Kesehatan. 2018;3(1):142-148

24. Sulistyaningsih DA, Panunggal B, Murbawani EA. Hubungan Antara Status Iodium Dan Panjang Badan Pada Anak Stunting Usia 1224 Bulan [Skripsi]. Semarang: Diponegoro University; 2018.

25. World Health Organization [Internet]. Ge- neva: Infant and young child feeding; [cited 2018 January 10]. Available from: https:// www.who.int/en/news-room/fact-sheets/detail/infant-and-young-child-feeding.

26. Joan Webster-Gandy AM, and Michelle Holdsworth. Oxford handbook of nutrition and dietetics. Jakarta: Penerbit Buku Kedokteran EGC; 2016 